\title{
High Temperature Oxidation Behavior of Yttrium Dioxide Coated Fe-20Cr Alloy
}

\author{
Marina Fuser Pillis ${ }^{a^{*}}$, Olandir Vercino Correa ${ }^{a}$, Lalgudi Venkataraman Ramanathan ${ }^{a}$ \\ ${ }^{a}$ Materials Science and Technology Center, Instituto de Pesquisas Energéticas e Nucleares - IPEN, \\ Av. Prof. Lineu Prestes, 2242, CEP 05508-000, São Paulo, SP, Brazil
}

Received: July 7, 2015; Revised: February 2, 2016; Accepted: March 11, 2016

\begin{abstract}
Long term isothermal and cyclic oxidation behavior of yttrium dioxide $\left(\mathrm{Y}_{2} \mathrm{O}_{3}\right)$ coated $\mathrm{Fe}-20 \mathrm{Cr}$ alloy was studied. Oxidation tests were carried out in air for periods of up to 200 hours at $1000^{\circ} \mathrm{C}$ and the oxidation behavior of the alloy was evaluated gravimetrically. The $\mathrm{Y}_{2} \mathrm{O}_{3}$ coating reduced markedly the mass gain of the alloy. Energy dispersive spectroscopic analysis of scale sections on oxidized $\mathrm{Y}_{2} \mathrm{O}_{3}$ coated specimens revealed a $\mathrm{Cr}$ rich layer close to the metal/oxide interface and the presence of $\mathrm{Y}$ and $\mathrm{Cr}$ near the oxide/air interface, indicating diffusion of $\mathrm{Cr}$ through the $\mathrm{Y}_{2} \mathrm{O}_{3}$ layer. Further evidence of this diffusion was seen as change in colour of the $\mathrm{Y}_{2} \mathrm{O}_{3}$ coating from white to green after prolonged oxidation. X-ray diffraction analysis of the scale revealed perovskite-type $\mathrm{YCrO}_{3}$. This study attributes the increased oxidation resistance of the $\mathrm{Y}_{2} \mathrm{O}_{3}$ coated $\mathrm{Fe}-20 \mathrm{Cr}$ alloy to increased oxygen ion diffusion through the $\mathrm{Cr}_{2} \mathrm{O}_{3}$ scale due to $\mathrm{YCrO}_{3}$ formation and grain boundary segregated $\mathrm{Y}$ ion blocking alloy cation diffusion.
\end{abstract}

Key words: Iron-chromium alloy, Yttrium dioxide, Coating, Oxidation behavior, High temperature

\section{INTRODUCTION}

Metallic materials for use at high temperatures are usually iron, nickel or cobalt based alloys. The oxides formed on these alloys in oxidizing environments are not sufficiently protective above $500^{\circ} \mathrm{C}$. Hence, chromium and/ or aluminium are added to these alloys to establish more protective oxides (scales) of chromium dioxide or alumina. Protection of the alloys by the chromium dioxide or alumina layer can be compromised by spalling or cracking of the oxides, often caused by growth or thermal stresses. The use of reactive elements, especially rare earths (RE) to improve high temperature oxidation resistance of chromium dioxide and alumina forming alloys is quite well documented. ${ }^{1-14}$ The improvements are in the form of reduced oxidation rates and increased scale adhesion. The RE can be added to the alloy in elemental form or as oxide dispersions. It can also be applied as an oxide coating to the alloy surface. ${ }^{3-7,15}$ Various mechanisms have been proposed to explain the effect of reactive elements in improving oxidation resistance and the most widely accepted mechanism attributes it to segregation of the reactive elements to the interface or to the oxide scale grain boundaries and blocking of $\mathrm{Cr}$ ion diffusion though the oxide scale ${ }^{8-11}$ Studies carried out by Seo et al., about the effect of addition of $\mathrm{Ce}, \mathrm{La}$ and $\mathrm{Y}$ to a $\mathrm{Fe}-22 \mathrm{Cr}-0.5 \mathrm{Mn}$ alloy on the oxidation behavior of the alloy at $800{ }^{\circ} \mathrm{C}$, indicated that $\mathrm{Y}$ was the most effective element to reduce the growth rate of the oxide scale. ${ }^{12}$ In recent years a number of studies have been carried out to exploit the benefits of rare earth additions on oxidation behavior of chromium dioxide and alumina forming alloys. ${ }^{13,14,16-21}$ Most studies reporting the reactive element effect in chromium dioxide forming alloys were carried out at or below $800{ }^{\circ} \mathrm{C}$. A limited number of

*e-mail:mfpillis@ipen.br studies have reported this effect at temperatures above $950^{\circ} \mathrm{C}$, probably attributable to formation of volatile $\mathrm{CrO}_{3}$. To throw more light on reactive element effect at a higher temperature and after prolonged periods when $\mathrm{CrO}_{3}$ formation is likely, this paper reports the effect of $\mathrm{Y}_{2} \mathrm{O}_{3}$ coating on oxidation behavior of $\mathrm{Fe}-20 \mathrm{Cr}$ alloy at $1000^{\circ} \mathrm{C}$ for $200 \mathrm{~h}$.

\section{METHODS AND MATERIALS}

The Fe-20Cr alloy (composition in wt-\% - 19.7Cr, 0.79Mn, $0.02 \mathrm{Si}$ and balance $\mathrm{Fe}$ ) was prepared in a vacuum induction furnace and the cast ingot was forged at $980^{\circ} \mathrm{C}$. Rectangular specimens with total area of approximately $4 \mathrm{~cm}^{2}$ were cut from the forged bar and its surfaces prepared by grinding with $\mathrm{SiC}$ paper to mesh size 220. The specimens were then degreased with acetone, dried and weighed in an analytical balance. A dispersion of $\mathrm{Y}_{2} \mathrm{O}_{3}$ powder (99.99\% purity) in ethanol was prepared and sprayed with an airbrush on to the different sides of the specimens at room temperature. The $\mathrm{Y}_{2} \mathrm{O}_{3}$ film coated specimens were then dried in air. The coating did not peel or dislodge indicating adequate adhesion. The coated specimens were again weighed. All the oxidation measurements were carried out in triplicate. Two sets of oxidation measurements were carried out. The first consisted of heating the bare and $\mathrm{Y}_{2} \mathrm{O}_{3}$ coated specimens in air in a muffle furnace at $1000{ }^{\circ} \mathrm{C}$ for $200 \mathrm{~h}$. The mass gain per unit area of the different specimens was determined. The second set of measurements was cyclic oxidation wherein each cycle consisted of heating the bare and $\mathrm{Y}_{2} \mathrm{O}_{3}$ coated specimens for $7 \mathrm{~h}$ at $1000{ }^{\circ} \mathrm{C}$ followed by cooling to room temperature. This was repeated 15 times. The mass gain per unit area of the bare and $\mathrm{Y}_{2} \mathrm{O}_{3}$ coated specimens was recorded after 
each cycle. The oxidation products on the specimen surfaces were examined using a scanning electron microscope and micro-regions on the oxidised specimen surfaces analyzed using an energy dispersive spectrometer (EDS). The chemical composition of the oxide scales was determined by x-ray diffraction (XRD) analysis.

\section{RESULTS AND DISCUSSION}

The average mass gains of the bare and $\mathrm{Y}_{2} \mathrm{O}_{3}$ coated Fe-20Cr alloy specimens after oxidation at $1000{ }^{\circ} \mathrm{C}$ for $200 \mathrm{~h}$ were 1.74 and $0.52 \mathrm{mg} / \mathrm{cm}^{2}$ respectively. The mass gains were due to formation of oxides of elements from the alloy and a marked decrease in mass gain of the $\mathrm{Y}_{2} \mathrm{O}_{3}$ coated specimen is evident. The morphological features of the three bare specimen surfaces after oxidation were identical. The surface of one of these specimens is shown in Fig. 1a and it reveals undulating mounds incrusted with fine cuboids of a mixture of oxides. An EDS spectrum of this surface is shown in Fig.1b and it reveals the presence of $\mathrm{Cr}$ and $\mathrm{Mn}$, besides oxygen. A cross section of the same specimen is shown in Fig. 1c and it reveals voids at the metal/oxide interface and near the oxide/air interface. EDS analyses at regions 1 and 2 in Fig. $1 \mathrm{c}$ indicate $\mathrm{Fe}, \mathrm{Cr}$ and $\mathrm{Mn}$ in quantities shown in Table 1. Region 2, close to the oxide/air interface has a high Mn content.

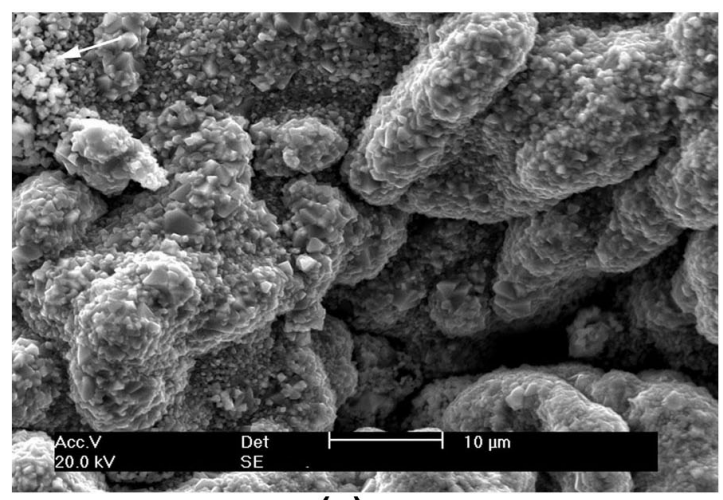

(a)
The XRD spectrum of the oxide on the oxidised bare specimen is shown in Fig. 2 and it reveals the oxide phases $\mathrm{Cr}_{2} \mathrm{O}_{3}$ and $\mathrm{MnCr}_{2} \mathrm{O}_{4}$. The EDS and XRD analyses data indicate that the oxide layer on the oxidised bare specimen consists mainly of $\mathrm{Cr}_{2} \mathrm{O}_{3}$ with $\mathrm{MnCr}_{2} \mathrm{O}_{4}$ spinel in the oxide near the oxide/air interface. The formation of and the location of the spinel suggests diffusion of $\mathrm{Mn}$ through the $\mathrm{Cr}_{2} \mathrm{O}_{3}$ layer, corroborating Wild's observation based on Auger spectroscopic measurements that the Mn ion diffuses faster than the $\mathrm{Cr}$ ion in $\mathrm{Cr}_{2} \mathrm{O}_{3}$ lattice. ${ }^{22}$ Hua et al., reported the formation of an outer layer of $\mathrm{Mn}_{2} \mathrm{O}_{3}$ over a layer of a $\mathrm{Mn}-\mathrm{Cr}$ spinel and this however was not observed in our study, due possibly to the lower Mn content. ${ }^{16}$

The surface features of the three $\mathrm{Y}_{2} \mathrm{O}_{3}$ coated specimens oxidised for $200 \mathrm{~h}$ at $1000{ }^{\circ} \mathrm{C}$ were also identical and a micrograph of one of these specimens, shown in Fig.3a, reveals cuboid clusters of the $\mathrm{Y}_{2} \mathrm{O}_{3}$ coating. The EDS spectrum of this surface is shown in Fig. $3 \mathrm{~b}$ and it reveals the presence of $\mathrm{O}$ and $\mathrm{Cr}$ besides $\mathrm{Y}$. A cross section of the same specimen is shown in Fig. 3c. This reveals a compact dark grey layer

Table 1: EDS analysis results of regions 1 and 2 in Fig.1c.

\begin{tabular}{ccccc}
\hline Region & \multicolumn{4}{c}{ Elements (wt\%) } \\
\hline & $\mathrm{O}$ & $\mathrm{Cr}$ & $\mathrm{Mn}$ & $\mathrm{Fe}$ \\
1 & 27.55 & 70.18 & 1.01 & 1.25 \\
2 & 20.39 & 52.84 & 25.9 & 0.87 \\
\hline
\end{tabular}

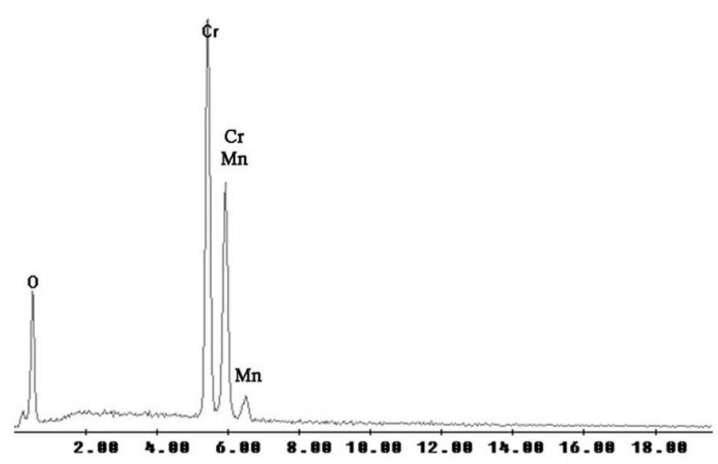

(b)

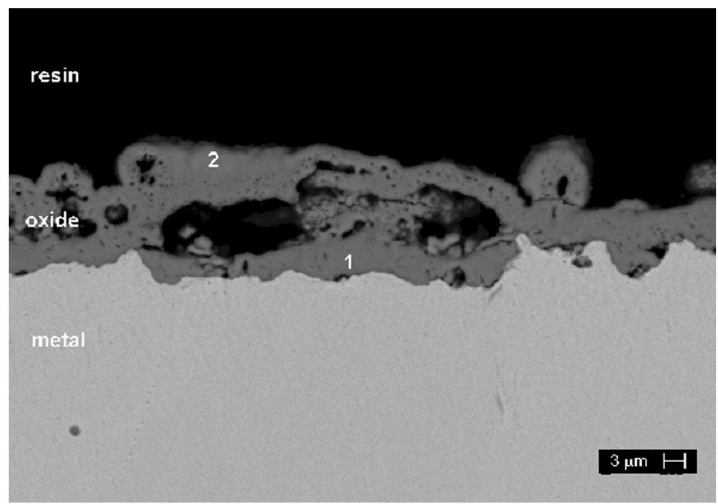

(c)

Figure 1: Scanning electron micrographs and the EDS spectrum of uncoated $\mathrm{Fe}-20 \mathrm{Cr}$ alloy specimen oxidized for $200 \mathrm{~h}$ at $1000^{\circ} \mathrm{C}$. (a) The surface; (b) the EDS spectrum of the surface; (c) cross section of the specimen. 
close to the alloy and EDS analyses at regions 1 and 2 revealed the elements shown in the Table 2. Region 1 is rich in $\mathrm{Cr}$ suggesting $\mathrm{Cr}_{2} \mathrm{O}_{3}$ formation by reaction of $\mathrm{Cr}$ from the alloy with $\mathrm{O}$ in the $\mathrm{Y}_{2} \mathrm{O}_{3}$ layer. Region 2 revealed $\mathrm{Cr}$ and $\mathrm{Mn}$, besides $\mathrm{Y}$, also suggesting diffusion of $\mathrm{Cr}$ and $\mathrm{Mn}$ through the inner $\mathrm{Cr}_{2} \mathrm{O}_{3}$ layer.

The XRD spectrum of the oxidised $\mathrm{Y}_{2} \mathrm{O}_{3}$ coated specimen is shown in Fig. 4 and it reveals $\mathrm{YCrO}_{3}$ in the scale, a perovskite oxide that formed from the reaction between $\mathrm{Cr}_{2} \mathrm{O}_{3}$ and $\mathrm{Y}_{2} \mathrm{O}_{3}$. No Mn containing phase was detected, due

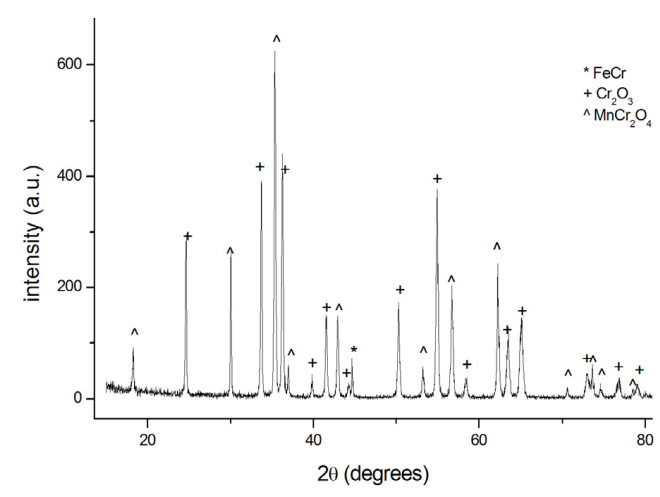

Figure 2: XRD spectrum of uncoated $\mathrm{Fe}-20 \mathrm{Cr}$ alloy specimen oxidized for $200 \mathrm{~h}$ at $1000^{\circ} \mathrm{C}$. possibly to the Mn content in region 2 of Fig. 3c being very small. Considering the elements detected in regions 1 and 2 of Fig. 3c, it is evident that the $\mathrm{YCrO}_{3}$ phase forms at regions between region 1 and region 2 . That is, the $\mathrm{Cr}$ which diffused through the $\mathrm{Cr}_{2} \mathrm{O}_{3}$ layer towards the $\mathrm{Y}_{2} \mathrm{O}_{3}$ layer forms $\mathrm{Cr}_{2} \mathrm{O}_{3}$ within the $\mathrm{Y}_{2} \mathrm{O}_{3}$ layer and these in turn react to form $\mathrm{YCrO}_{3}$.

Figure 5 shows the average mass gain after each oxidation cycle of the bare and $\mathrm{Y}_{2} \mathrm{O}_{3}$ coated specimens. Every point in this figure represents the average value of mass gained by three specimens at the end of a specific cycle of oxidation. The average mass gains of the bare and the coated specimens were very high during the first four cycles and thereafter remained almost unchanged. None of the specimens spalled, even after 15 cycles. The higher mass gains during the first four cycles of oxidation is indicative of a transient stage and formation of $\mathrm{MnCr}_{2} \mathrm{O}_{4}$, besides $\mathrm{Cr}_{2} \mathrm{O}_{3}$. Evidence of this is shown henceforth in the EDS and XRD analyses results of these specimens. After the $7^{\text {th }}$ cycle the mass gains are almost constant indicating steady growth of the $\mathrm{Cr}_{2} \mathrm{O}_{3}$ layer.

Table 2: EDS analysis results of regions 1 and 2 in Fig.3c.

\begin{tabular}{cccccc}
\hline Region & \multicolumn{5}{c}{ Elements (wt\%) } \\
\hline & $\mathrm{O}$ & $\mathrm{Cr}$ & $\mathrm{Mn}$ & $\mathrm{Fe}$ & $\mathrm{Y}$ \\
1 & 32.4 & 66.6 & - & 1.0 & - \\
2 & 23.6 & 8.3 & 0.5 & - & 67.6 \\
\hline
\end{tabular}

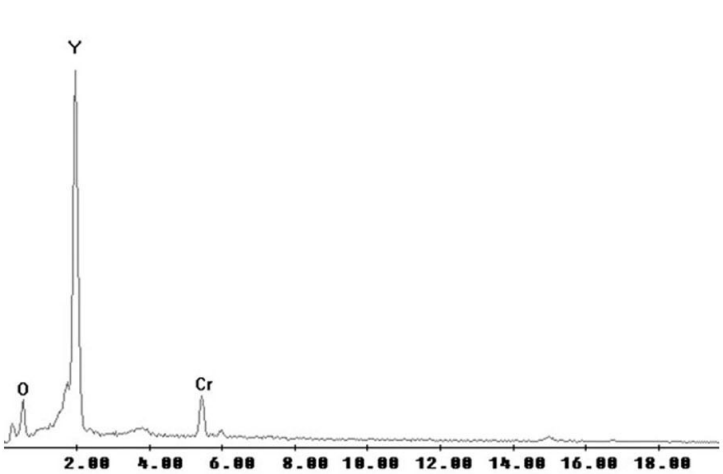

(b)

(a)

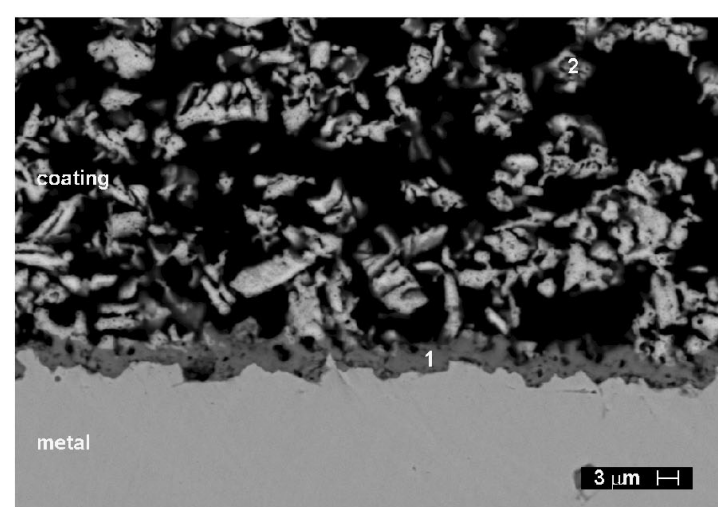

(c)

Figure 3: Scanning electron micrographs and the EDS spectrum of $\mathrm{Y}_{2} \mathrm{O}_{3}$ coated $\mathrm{Fe}-20 \mathrm{Cr}$ alloy specimen oxidized for $200 \mathrm{~h}$ at $1000^{\circ} \mathrm{C}$. (a) The surface; (b) the EDS spectrum of the surface; (c) cross-section. 
The surface features of the three bare specimens after 15 cycles of oxidation were identical and Fig 6a shows the features of one of the specimens. Some thermal stress induced cracks can be seen but there is no evidence of spalling. The EDS spectrum of this surface is shown in Fig. $6 \mathrm{~b}$ and it reveals that the oxide is rich in $\mathrm{Cr}$ and contains $\mathrm{Mn}$, similar to that observed on specimens that were oxidised for $200 \mathrm{~h}$ at $1000^{\circ} \mathrm{C}$. Fig. $6 \mathrm{c}$ shows the cross section of this specimen and it reveals voids at the metal/oxide interface. The results of EDS analyses at regions 1 and 2 are shown in Table 3. Region 1 is a $\mathrm{Cr}$ rich oxide with traces of $\mathrm{Fe}$ and region 2, close to the oxide/gas interface reveals Mn, besides Fe and Cr. XRD analysis of the bare specimen surface after 15 cycles of oxidation revealed $\mathrm{Cr}_{2} \mathrm{O}_{3}$ and $\mathrm{MnCr}_{2} \mathrm{O}_{4}$, similar to that observed on the surface of the specimen that was oxidised for $200 \mathrm{~h}$ at $1000^{\circ} \mathrm{C}$.

The surface features of the three $\mathrm{Y}_{2} \mathrm{O}_{3}$ coated specimens after 15 cycles of oxidation were identical and as shown in Fig. 7a. No spalling was observed and the morphology of the surface oxide was similar to that of the specimen oxidised for $200 \mathrm{~h}$ at $1000^{\circ} \mathrm{C}$ (Fig. 3a). The EDS spectrum of the surface in Fig 7a is shown in Fig. 7b. The elements $\mathrm{Y}$ and $\mathrm{Cr}$ were detected, indicating $\mathrm{Cr}$ diffusion to the outer layer. The cross section of the cyclically oxidised $\mathrm{Y}_{2} \mathrm{O}_{3}$ coated specimen is

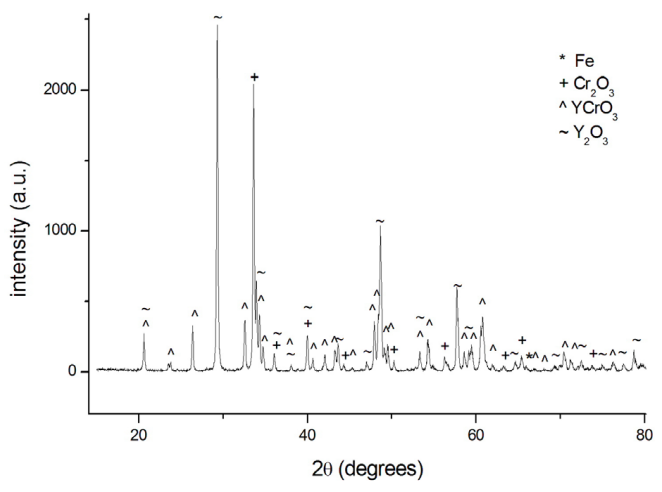

Figure 4: XRD spectrum of $\mathrm{Y}_{2} \mathrm{O}_{3}$ coated $\mathrm{Fe} 20 \mathrm{Cr}$ alloy specimen oxidized for $200 \mathrm{~h}$ at $1000{ }^{\circ} \mathrm{C}$.

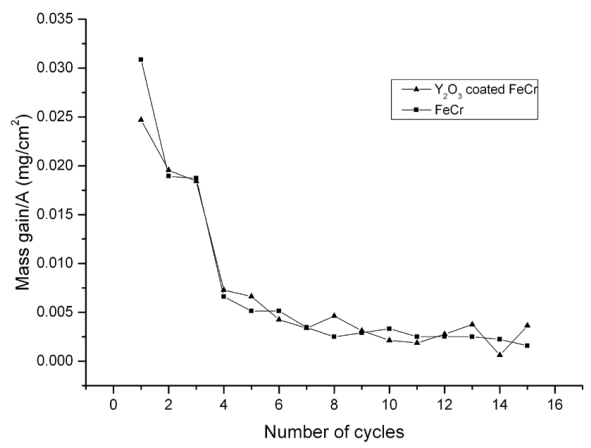

Figure 5: Mass gain per unit area after each cycle of $7 \mathrm{~h}$ at 1000 ${ }^{\circ} \mathrm{C}$ followed by cooling to room temperature of uncoated and $\mathrm{Y}_{2} \mathrm{O}_{3}$ coated $\mathrm{Fe}-20 \mathrm{Cr}$ specimens. shown in Fig. 7c. The results of EDS analysis at regions 1, 2 and 3 are shown in Table 4 . Region 1 revealed $\mathrm{Cr}$ with some $\mathrm{Fe}$, while regions 2 and 3 in the $\mathrm{Y}_{2} \mathrm{O}_{3}$ coating revealed $\mathrm{Y}$ and $\mathrm{Cr}$ as foreseen. The $\mathrm{Cr}$ content in region 3 is less than that in region 2 , indicating its diffusion from the substrate through the $\mathrm{Y}_{2} \mathrm{O}_{3}$ layer. The results of XRD analysis of the oxide scale on the $\mathrm{Y}_{2} \mathrm{O}_{3}$ coated specimen oxidised cyclically revealed the phases $\mathrm{Cr}_{2} \mathrm{O}_{3}, \mathrm{Y}_{2} \mathrm{O}_{3}$ and $\mathrm{YCrO}_{3}$, quite similar to that on the specimen that was oxidised for $200 \mathrm{~h}$ at $1000^{\circ} \mathrm{C}$.

Macroscopic observations of the $\mathrm{Y}_{2} \mathrm{O}_{3}$ coated specimens oxidised cyclically revealed that after each cycle, increasing areas of the coating became dark and eventually green. This colour change is due to chromium diffusion through the $\mathrm{Y}_{2} \mathrm{O}_{3}$ coating, evidence of which can be seen in Table 4 .

\section{GENERAL DISCUSSION}

Oxidation of iron-chromium alloys at temperatures above $950{ }^{\circ} \mathrm{C}$ and under high oxygen pressures leads not only to formation of $\mathrm{Cr}_{2} \mathrm{O}_{3}$ on the surface of the alloy but reaction of the $\mathrm{Cr}_{2} \mathrm{O}_{3}$ with $\mathrm{O}_{2}$ to form volatile $\mathrm{CrO}_{3} \cdot{ }^{23}$ At $1000{ }^{\circ} \mathrm{C}$ and at constant oxygen pressure, mass loss caused by conversion of $\mathrm{Cr}_{2} \mathrm{O}_{3}$ to $\mathrm{CrO}_{3}$ is constant with time. Hence the observed mass gains of the bare and the $\mathrm{Y}_{2} \mathrm{O}_{3}$ coated specimens oxidised for $200 \mathrm{~h}$ at $1000{ }^{\circ} \mathrm{C}$ indicate that the rate of $\mathrm{Cr}_{2} \mathrm{O}_{3}$ formation is higher than the rate of conversion of $\mathrm{Cr}_{2} \mathrm{O}_{3}$ to $\mathrm{CrO}_{3}$. The mass gain of the bare specimens oxidised at $1000{ }^{\circ} \mathrm{C}$ for $200 \mathrm{~h}$ was significantly higher than that of the $\mathrm{Y}_{2} \mathrm{O}_{3}$ coated specimens oxidised under the same conditions. This indicates that the higher mass gain of the bare specimen compared with the $\mathrm{Y}_{2} \mathrm{O}_{3}$ coated specimen is due to formation of significantly more $\mathrm{Cr}_{2} \mathrm{O}_{3}$ in the former and that the $\mathrm{Y}_{2} \mathrm{O}_{3}$ coating affects markedly the oxidation rate of the Fe-20Cr alloy. The micrographs, the EDS spectra and XRD data of the bare specimens oxidised for $200 \mathrm{~h}$ at $1000^{\circ} \mathrm{C}$ reveal that the oxide formed was intact and its growth due to predominant alloy cation diffusion, demonstrating thus parabolic growth behaviour. The growth of oxide on the $\mathrm{Y}_{2} \mathrm{O}_{3}$ coated specimens oxidized for $200 \mathrm{~h}$ at $1000{ }^{\circ} \mathrm{C}$ was also parabolic, but due to predominant oxygen ion diffusion as shown below.

The structure and composition of the oxide formed on specimens oxidised for $200 \mathrm{~h}$ at $1000{ }^{\circ} \mathrm{C}$ and cyclically were identical. The scale on the bare and coated specimens

Table 3: EDS analysis results of regions 1 and 2 in Fig.6c.

\begin{tabular}{ccccc}
\hline Region & \multicolumn{4}{c}{ Elements $(\mathbf{w t} \%)$} \\
\hline & $\mathrm{O}$ & $\mathrm{Cr}$ & $\mathrm{Mn}$ & $\mathrm{Fe}$ \\
2 & 32.58 & 66.73 & - & 0.69 \\
& 14.89 & 54.31 & 29.59 & 1.21 \\
\hline
\end{tabular}

Table 4: EDS analysis results of regions 1, 2 and 3 in Fig.7c.

\begin{tabular}{ccccc} 
Region & \multicolumn{2}{c}{ Elements (wt\%) } & & \\
& $\mathrm{O}$ & $\mathrm{Cr}$ & $\mathrm{Fe}$ & $\mathrm{Y}$ \\
1 & 29.92 & 66.58 & 3.5 & - \\
2 & 23.88 & 25.14 & - & 50.98 \\
3 & 24.00 & 13.59 & - & 62.41 \\
\hline
\end{tabular}




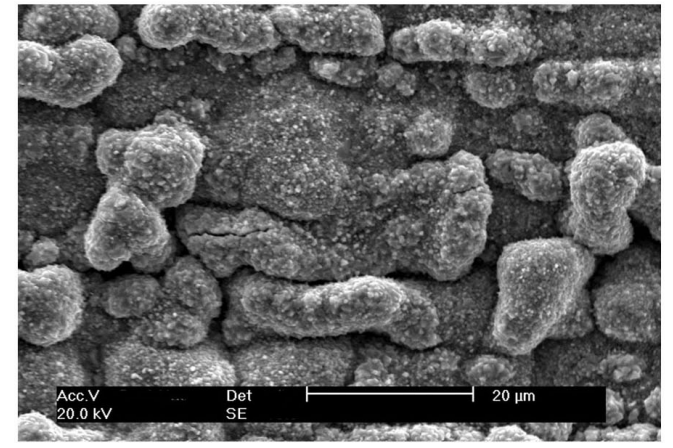

(a)

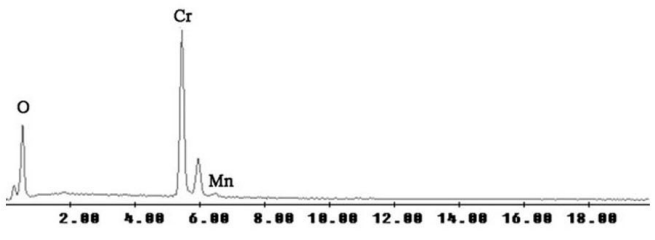

(b)

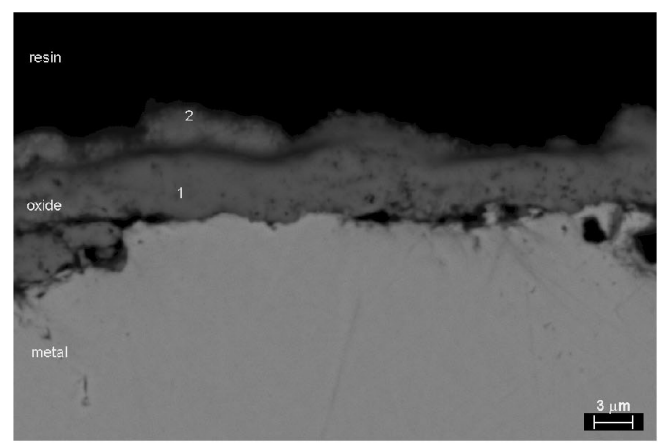

(c)

Figure 6: Scanning electron micrographs and the EDS spectrum of Fe-20Cr alloy specimen after 15 cycles of oxidation for $7 \mathrm{~h}$ at $1000^{\circ} \mathrm{C}$. (a) The surface; (b) the EDS spectrum of the surface; (c) the cross-section.

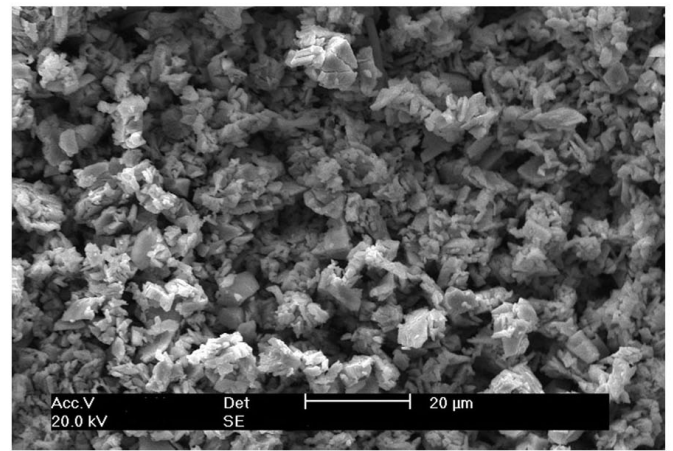

(a)

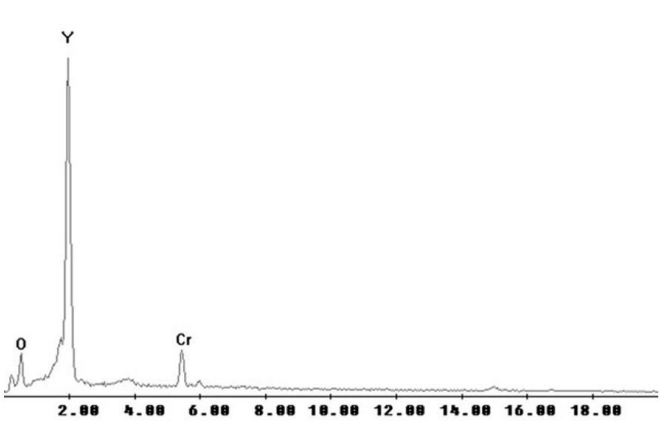

(b)

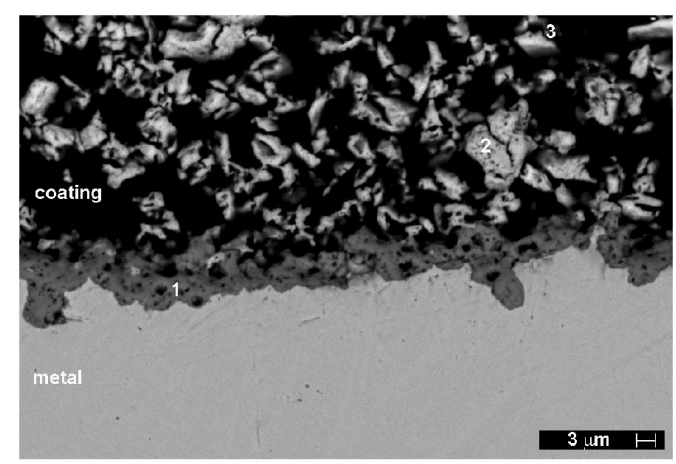

(c)

Figure 7: Scanning electron micrographs and the EDS spectrum of $\mathrm{Y}_{2} \mathrm{O}_{3}$ coated $\mathrm{Fe}-20 \mathrm{Cr}$ alloy specimen after 15 cycles of oxidation for $7 \mathrm{~h}$ at $1000{ }^{\circ} \mathrm{C}$. (a) The surface; (b) the EDS spectrum of the surface; (c) the cross-section. 
did not spall even after 15 cycles of oxidation. Oxidation of $\mathrm{Y}_{2} \mathrm{O}_{3}$ coated $\mathrm{Fe}-20 \mathrm{Cr}$ specimens can be considered to consist of an initial transient stage during which a thin layer of $\mathrm{Cr}_{2} \mathrm{O}_{3}$ forms on the alloy surface. Formation of this layer has been reported to be aided by $\mathrm{Y}_{2} \mathrm{O}_{3}$ acting as nucleation sites. ${ }^{24,25}$ This stage is followed by oxidation at a much lower rate with $\mathrm{Cr}$ diffusing through the $\mathrm{Cr}_{2} \mathrm{O}_{3}$ layer to form $\mathrm{Cr}_{2} \mathrm{O}_{3}$ in the $\mathrm{Y}_{2} \mathrm{O}_{3}$ coating. These two oxides react to form perovskite-type oxide $\mathrm{YCrO}_{3}$ which increases in quantity with time at temperature. In this study the scale on the $\mathrm{Y}_{2} \mathrm{O}_{3}$ coated $\mathrm{Fe}-20 \mathrm{Cr}$ specimen oxidised for $200 \mathrm{~h}$ at $1000{ }^{\circ} \mathrm{C}$ consisted of $\mathrm{Cr}_{2} \mathrm{O}_{3}, \mathrm{Y}_{2} \mathrm{O}_{3}$ and $\mathrm{YCrO}_{3}$. Chevalier and Larpin also detected $\mathrm{Y}_{2} \mathrm{O}_{3}, \mathrm{Cr}_{2} \mathrm{O}_{3}$ and $\mathrm{YCrO}_{3}$ in the scale on $\mathrm{Y}_{2} \mathrm{O}_{3}$ coated $\mathrm{Fe}-30 \mathrm{Cr}$ alloy oxidised at $1000^{\circ} \mathrm{C}$ for $100 \mathrm{~h}$ and also in an equimolar powder mixture of $\mathrm{Y}_{2} \mathrm{O}_{3}$ and $\mathrm{Cr}_{2} \mathrm{O}_{3}$ heated for $288 \mathrm{~h}$ at $1000{ }^{\circ} \mathrm{C}$, the latter indicating that formation of $\mathrm{YCrO}_{3}$ phase is a very slow process. ${ }^{26}$

The lower oxidation rate of the $\mathrm{Y}_{2} \mathrm{O}_{3}$ coated alloy compared to the bare alloy is due to formation of $\mathrm{YCrO}_{3}$ which brings about an increase in oxygen ion vacancies in the chromia scale and consequent increase in diffusion of oxygen ions to the scale/alloy interface. ${ }^{25,27}$ Other studies have also reported the reduced oxidation rates of $\mathrm{Y}$ containing or $\mathrm{Y}_{2} \mathrm{O}_{3}$ coated $\mathrm{Fe}-\mathrm{Cr}$ alloys to formation of $\mathrm{YCrO}_{3}$ and/or $\mathrm{YCrO}_{4} \cdot{ }^{26,28-34}$ It has also been reported that below $1100{ }^{\circ} \mathrm{C}$ oxidation is dominated by short circuit diffusion. ${ }^{35}$ That is, the oxide scale grain boundaries are fast diffusion paths for migrating ions. In $\mathrm{Y}$ containing or $\mathrm{Y}_{2} \mathrm{O}_{3}$ coated alloys, the $\mathrm{Y}$ ion in the oxide scale segregates to the grain boundaries and its radius $(1.02 \AA)$ being larger than the $\mathrm{Cr}$ and $\mathrm{Fe}$ ions $(0.615 \AA$ and $0.78 \AA$ respectively) blocks the path of the diffusing alloy cations, decreasing thereby the oxidation rate of the alloy. ${ }^{6,36}$ Hence, the influence of the $\mathrm{Y}_{2} \mathrm{O}_{3}$ coating in reducing the oxidation rate of chromia forming alloys is twofold. It increases oxygen ion vacancies and thereby oxygen ion diffusion in the $\mathrm{YCrO}_{3}$ compound. It also decreases $\mathrm{Cr}$ ion diffusion rate along $\mathrm{Cr}_{2} \mathrm{O}_{3}$ grain boundaries due to the presence of the segregated $\mathrm{Y}$ ions. Indirect proof of segregation of $\mathrm{Y}$ ions to the $\mathrm{Cr}_{2} \mathrm{O}_{3}$ grain boundaries is evident from the marked

\section{REFERENCES}

1. Hou PY, Stringer J. The effect of surface-applied reactive metal oxides on the high temperature oxidation of alloys. Materials Science and Engineering. 1987;87:295-302.

2. Rhys-Jones TN, Grabke HJ, Kudielka H. The effects of various amounts of alloyed cerium and cerium oxide on the high temperature oxidation of $\mathrm{Fe}-10 \mathrm{Cr}$ and $\mathrm{Fe}-20 \mathrm{Cr}$ alloys. Corrosion Science. 1987;27(1):49-63. Doi: http://dx.doi. org/10.1016/0010-938X(87)90119-3

3. Ecer GM, Singh RB, Meier GH. The influence of superficially applied oxide powders on the high-temperature oxidation behavior of $\mathrm{Cr}_{2} \mathrm{O}_{3}$-forming alloys. Oxidation of Metals. 1982;18(1-2):5581.

4. Stringer J. The reactive element effect in high temperature corrosion. Materials Science and Engineering A. 1989;120:129137.

5. Pillis MF, Ramanathan, LV. High temperature oxidation of rare earth chromite coated $\mathrm{Fe}-20 \mathrm{Cr}$ and $\mathrm{Fe}-20 \mathrm{Cr}-4 \mathrm{Al}$ alloys. Materials Research. 2007;10 (3):279-282. reduction in the rate of $\mathrm{Cr}_{2} \mathrm{O}_{3}$ formation on the $\mathrm{Y}_{2} \mathrm{O}_{3}$ coated specimen compared to that on the bare specimen oxidised at $1000^{\circ} \mathrm{C}$. Increase in oxidation resistance of chromia forming alloys in the presence of $\mathrm{Y}$ has been also explained by the interface segregation mechanism. ${ }^{37}$ Seo et al., showed using depth profiling studies on $\mathrm{Y}$ containing $\mathrm{Fe}-22 \mathrm{Cr}-0.5 \mathrm{Mn}$ alloy specimens oxidised at $800{ }^{\circ} \mathrm{C}$ that $\mathrm{Y}$ segregated at the alloy/oxide interface and suppressed outward $\mathrm{Cr}$ ion diffusion. ${ }^{12}$ This mechanism may be valid to a greater extent when the reactive element is added to the alloy.

\section{CONCLUSIONS}

1. The oxide layer formed on $\mathrm{Fe}-20 \mathrm{Cr}$ alloy oxidised isothermally at $1000{ }^{\circ} \mathrm{C}$ for $200 \mathrm{~h}$ and cyclically between $1000{ }^{\circ} \mathrm{C}$ and room temperature consisted of mainly $\mathrm{Cr}_{2} \mathrm{O}_{3}$. This oxide layer contained $\mathrm{MnCr}_{2} \mathrm{O}_{4}$ near the oxide/air interface.

2. The oxide layer formed on $\mathrm{Y}_{2} \mathrm{O}_{3}$ coated $\mathrm{Fe}-20 \mathrm{Cr}$ alloy oxidised at $1000^{\circ} \mathrm{C}$ for $200 \mathrm{~h}$ and cyclically contained $\mathrm{YCrO}_{3}$.

3. Compared to the uncoated alloy a marked decrease in mass gain of the coated alloy was observed and attributed to formation of the $\mathrm{YCrO}_{3}$ phase.

4. The oxide on the specimen surfaces did not spall during the cyclic oxidation tests.

5. During the cyclic oxidation tests, the $\mathrm{Y}_{2} \mathrm{O}_{3}$ coating remained adhered to the substrate and its colour changed gradually from white to dark green with increase in duration of oxidation.

6. The effect of $\mathrm{Y}_{2} \mathrm{O}_{3}$ coating in reducing the oxidation rate is twofold. It increases oxygen ion diffusion in the $\mathrm{YCrO}_{3}$ compound and segregation of $\mathrm{Y}$ ion to scale grain boundaries with resultant reduction in diffusion rate of alloy cations.

6. Pillis MF, Araújo, EG, Ramanathan, LV. Effect of rare earth additions on oxidation behavior of AISI304L stainless steel. Materials Research. 2006;9(4):375-379.

7. Pillis MF, Araújo, EG, Ramanathan, LV. Effect of addition of rare earth oxide concentrates on oxidation resistance of AISI304L. Materials Science Forum. 2006; 530-531:99-104.

8. Yurek GJ, Przybylski K, Garratt-Reed AJ. Segregation of Y to grain-boundaries in $\mathrm{Cr}_{2} \mathrm{O}_{3}$ and $\mathrm{NiO}$ scales formed on an ODS alloy. Journal of Electrochemical Society. 1987;134(10):26432644. doi: http://dx.doi.org/10.1149/1.2100264

9. Cotell CM, Yurek GJ, Hussey RJ, Mitchell DF, Graham MJ. The influence of grain-boundary segregation of yttrium in chromium dioxide on the oxidation of Cr metal II. Effects of temperature and dopand concentration. Oxidation of Metals. 1990;34(3-4): 201-216. Doi http://dx.doi.org/10.1007/BF00665015

10. Przybylski K, Garratt-Reed AJ, Yurek GJ. Grain-boundary segregation of yttrium in chromia scales. Journal of Electrochemical Society, 1988;135(2):509-517. Doi: http:// dx.doi.org/10.1149/1.2095646 
11. Papaiacovou P, Hussey RJ, Mitchell DF, Graham MJ. The effect of $\mathrm{CeO}_{2}$ coatings on the oxidation behavior of $\mathrm{Fe}-20 \mathrm{Cr}$ alloys in $\mathrm{O}_{2}$ at 1173K, Corrosion Science. 1990;30 (4-5):451-460.

12. Seo HS, Jin G, Jun JH, Kim DH, Kim KY. Effect of reactive elements on oxidation behavior of $\mathrm{Fe}-22 \mathrm{Cr}-0.5 \mathrm{Mn}$ ferritic stainless steel for a solid oxide fuel cell interconnect, Journal of Power Sources. 2008;178(1):1-8. Doi: http://dx.doi.org/10.1016/j. jpowsour.2007.12.026

13. Amano T. Rare earth application for heat-resisting alloys. Journal of Rare Earths. 2010;28:12-21. Doi: http://dx.doi. org/10.1016/S1002-0721(10)60371-7

14. Wang L, Du X, Gan Y, Liu L, Ye X, Jiang L. Effect of rare earths on oxidation resistance of heat resistant steel. Journal of Rare Earths. 2010;28:489-491. doi: http://dx.doi.org/10.1016/ S1002-0721(10)60305-5

15. Ghosh D, Mukherjee S, Das S, High temperature oxidation behaviour of yttria $\left(\mathrm{Y}_{2} \mathrm{O}_{3}\right)$ coated low alloy steel. Surface Engineering. 2014; 30(7):524-528. DOI: http://dx.doi.org/10. 1179/1743294414Y.0000000271

16. Hua B, Pu J, Lu F, Zhang J, Chi B, Jian L, et al. Development of a $\mathrm{Fe}-\mathrm{Cr}$ alloy for interconnect application in intermediate temperature solid oxide fuel cells. Journal of Power Sources. 2010;195(9):2782-2788. doi: http://dx.doi.org/10.1016/j. jpowsour.2009.08.077

17. Guo P, Zeng C, Shao Y. Effect of $\mathrm{LaCrO}_{3}$ coating on high temperature oxidation of type 316 stainless steel. Journal of Rare Earths. 2011;29(7):698-701. doi: http://dx.doi.org/10.1016/ S1002-0721(10)60525-X

18. Zhang YD, Zhang C, Lan H, Hou PY, Yang ZG. Improvement of the oxidation resistance of Tribaloy T- 800 alloy by the addition of yttrium and aluminium, Corrosion Science. 2011;53(3):10351043. doi: http://dx.doi.org/10.1016/j.corsci.2010.11.038

19. Kim SH, Huh JY, Jun JH, Favergeon J. Thin elemental coatings of yttrium, cobalt, and yttrium/cobalt on ferritic stainless steel for SOFC interconnect applications. Current Applied Physics. 2010;10 (Suppl 2)S86-S90. doi: http://dx.doi.org/10.1016/j. cap.2009.11.049

20. Ramanathan LV, Pillis MF, Fernandes SMC. Role of rare earth oxide coating on oxidation resistance of chromia-forming alloys. Journal of Materials Science. 2008; 43(2):530-535. DOI: http:// dx.doi.org/10.1007/s10853-007-1855-8

21. Pillis MF, Correa OV, Araujo EG, Ramanathan LV. Oxidation behavior of $\mathrm{FeCr}$ and $\mathrm{FeCrY}$ alloys coated with an aluminium based paint. Materials Research. 2008;11(3): 251-256. http:// dx.doi.org/10.1590/S1516-14392008000300004

22. Wild RK. High temperature oxidation of austenitic stainless steel in low oxygen pressure. Corrosion Science. 1977;17(2):87-93.

23. Birks N, Meier GH. Introduction to High Temperature Oxidation of Metals. London; Edward Arnold; 1983.

24. Diaz LM, Zhu J, Holcomb GR, Jablonski PD, Alman DE, Sridhar S. Fundamental studies on the transient stages of scale growth in Fe-22 wt\% Cr alloys. Defect and Diffusion Forum.
2009;283-286:425-431. DOI: http://dx.doi.org/10.4028/www. scientific.net/DDF.283-286.425

25. Saito Y, Onay B, Maruyama T. The reactive element effect (REE) in oxidation of alloys. Journal de Physique IV. 1993:3:C9217-C9-230. http://dx.doi.org/10.1051/jp4:1993920

26. Chevalier S, Larpin JP. Formation of perovskite type phases during the high temperature oxidation of stainless steels coated with reactive element oxides. Acta Materialia. 2002;50(12):31053114. doi: http://dx.doi.org/10.1016/S1359-6454(02)00106-4

27. Harris DJ, Harding JH, Watson GW. Computer simulation of the reactive element effect in $\mathrm{NiO}$ grain boundaries. Acta Materialia. 2000;48(12):3039 -3048. doi: http://dx.doi.org/10.1016/S13596454(00)00131-2

28. Riffard F, Buscail H, Caudron E, Cueff R, Issartel C, Perrier S. In-situ characterization of the oxide scale formed on yttriumcoated 304 stainless steel at $1000^{\circ}$ C.Materials Characteristics. 2002;49(1):55-65. doi: http://dx.doi.org/10.1016/S10445803(02)00278-4

29. Seybolt AU. High temperature oxidation of chromium containing $\mathrm{Y}_{2} \mathrm{O}_{3}$. Corrosion Science. 1966;6(6):263-266.

30. Ramanarayanan TA, Mumford JD, Chun CM, Petkovic RA. Transport through chromia films. Solid State Ionics. 2000;136137:83-90. DOI: http://dx.doi.org/10.1016/S0167-2738(00)00355-6

31. Stroosnijder MF, Sunderkotter JD, Cristóbal MJ, Jenett H, Isenbugel K, Baker MA. The influence of Yttrium ion implantation on the oxidation behavior of powder metallurgically produced chromium. Surface Coatings Technology. 1996;83(1-3): 205211.

32. Tonghe $Z$, Jindong $X$, Chengzhou J, Jun $C$, Hong $X$, Jing $\mathrm{L}$, et al. Influence of the structure of implanted steel with Y, Y+C and $\mathrm{Y}+\mathrm{Cr}$ on the behaviors of wear, oxidation and corrosion resistance. Surface Coatings Technology.1995;72(1): 93-98. doi: http://dx.doi.org/10.1016/0257-8972(94)02337-9

33. Stroosnijder MF. Ion implantation for high temperature corrosion protection. Surface Coatings Technology. 1998;100-101(13):196-201.

34. Cristóbal MJ, Gibson PN, Stroosnijder MF. A study of the initial stages of oxidation of yttrium-implanted chromium using X-ray diffraction and absorption spectroscopy. Corrosion Science. 1996;38(6):805-822. doi: http://dx.doi.org/10.1016/0010938X(95)00168-J

35. Polman EA, Fransen T, Gellings PJ. The reactive element effect: ionic processes of grain boundary segregation and diffusion in chromium oxide scales. Journal of Physics Condensed Matter. 1989;1(28):4497-4510.

36. Hussey RJ, Graham MJ. The influence of reactive-element coatings on the high-temperature oxidation of pure-Cr and highCr-content alloys. Oxidation of Metals. 1996;45 (3-4):349-374. DOI http://dx.doi.org/10.1007/BF01046989

37. Hou PY, Stringer J. The effect of reactive element additions on the selective oxidation, growth and adhesion of chromia scales. Materials Science and Engineering A. 1995; 202(1-2):1-10. doi: http://dx.doi.org/10.1016/0921-5093(95)09798-8 